(C) 2017

Кулик М. І., кандидат сільськогосподарських наук

Полтавська державна аграрна академія

\title{
УРОЖАЙНІСТЬ ВЕГЕТАТИВНОЇ НАДЗЕМНОЇ МАСИ ПРОСА ПРУТОПОДІБНОГО ЗАЛЕЖНО ВІД ЗАСТОСУВАННЯ ПІДЖИВЛЕННЯ
}

\author{
Рецензент - доктор сільськогосподарських наук, професор М. Я. Шевніков
}

\begin{abstract}
Встановлено зміну елементів продуктивності (висоти та густоти стеблостою) проса прутоподібного залежно від застосування підживлень під час відновлення вегетації рослин. Визначено вплив позакореневого підживлення препаратом Кристалон на урожайність фітомаси культури в розрізі років дослідження. Наведено кореляційні залежності між кількісними показниками рослин третього-п'ятого років вететації та урожайністю фітомаси. Визначено, щзо урожайність вететативної надземної маси проса прутоподібного в більшій мірі обумовлюється вмістом сухої речовини у фітомасі, кількістю стебел на одиницюю площзі, в меншій мірі - висотою рослин у випадку застосування весняного підживлення фітоиченозу.
\end{abstract}

Ключові слова: просо прутоподібне, елементи продуктивності, підживлення, урожайність, корелячія, фітомаса.

Постановка проблеми. На даний час, динаміка зростання кількості населення планети, а також індустріалізаційні процеси в економіці, наслідком яких стало збільшення темпів виробництва, стали причиною зростання обсягів споживання енергетичних ресурсів у світі. Найбільш швидкі темпи спостерігаються в країнах Азії й особливо в Китаї, на частку якого припала практично половина світового приросту енергоспоживання [1].

Визначено, що виробництво, постачання та споживання непоновлюваних енергетичних ресурсів призводить до значного негативного впливу на навколишнє природне середовище $\mathrm{i}$ здоров'я людей. Так, сучасна енергетика емітує значний обсяг викидів вуглекислого газу, метану, оксидів сірки, оксидів азоту і летких органічних сполук [10]. Зважаючи на те, що Україна входить до переліку країн, які підписали та ратифікували Рамкову конвенцію ООН про зміну клімату [2] та Кіотський протокол [3] до неї, що передбачають захист кліматичної системи для сучасного і майбутнього поколінь людства, виникає потреба у виконанні своїх зобов'язань щодо скорочення викидів парникових газів до 2030 року.

Поряд 3 цим, в умовах дефіциту енергоресурсів все більше уваги приділяється можливості використання енергетичних культур та рослинних решток сільськогосподарського господарства як альтернативних джерел енергії. Розвиток програм виробництва палива 3 відновлюваних джерел рослинної сировини дасть змогу зменшити в майбутньому дефіцит вуглеводневої сировини для виробництва палива. Світова індустрія альтернативних джерел енергії характеризується наявністю широкого спектру заходів законодавчого та нормативно-правового забезпечення розвитку біоенергетики, а також державних програм, спрямованих на збільшення виробництва біопалива в певній країні [5]. Як наслідок, у світі спостерігається невпинне зростання виробництва енергетичних ресурсів 3 відновлюваних джерел, з-поміж яких значного розвитку набувають енергоносії біологічного походження. Проте в Україні лише $2 \%$ спожитої енергії від ії загального обсягу одержують з біомаси, тоді як у Західній Європі цей показник становить 10-12 \%, а в низці скандинавських країн - від 17 до $40 \%$.

Саме тому, наукова спільнота акцентує увагу на можливості забезпечення власних енергетичних потреб 3 урахуванням відновлювальних джерел енергії, зокрема на сталий розвиток біоенергетики за рахунок використання наявної ресурсної бази. Численні публікації не лише науковців, але й практиків, що вже мають досвід використання поновлювальних енергетичних ресурсів, свідчать про значні напрацювання та перспективи нашої держави щодо зниження рівня енергетичної залежності, зміцнення економічної та національної безпеки в цілому. Тому, для розвитку та реалізації даного напрямку, актуальним питанням сьогодення $€$ вивчення аспектів та удосконалення технології вирощування енергетичних культур за використання їхньої сировини для виробництва біопалива.

Аналіз основних досліджень і публікацій, у яких започатковано розв'язання проблеми. На даний час визначено, що за природноекономічними чинниками Україна належить до країн зі сприятливими умовами для забезпечення продовольчої безпеки, має високий потенціал створення стабільного ринку енергетичних куль- 
тур та використання їхньої сировини в біопаливній промисловості [8].

Як зазначають Г. Г. Гелетуха, Т. А. Желєзна, А. І. Баштовий [6], основними критеріями вибору того чи іншого варіанту у комерційних проектах ТЕЦ на біомасі $є$ забезпечення максимального прибутку від продажу теплової та електричної енергії, при цьому обмежуючим фактором є доступна кількість паливної біомаси. Цю проблему можна компенсувати шляхом вирощування енергетичних культур в промислових масштабах на землях не сільськогосподарського призначення, забруднених і деградованих грунтах.

Протягом тривалого часу вітчизняні та зарубіжні науковці вивчають можливості використання біопаливного потенціалу енергетичних культур, з них найбільш поширеними є представники родів Miscanthus, Salix, Populus та Panicum (просо прутоподібне - надалі світчграс).

За вивчення інтродукції світчграсу в нашій країні визначено, що ця культура добре адаптована до умов вирощування, формує потужний стеблостій, велику врожайність фітомаси (сировини для виробництва біопалива) та забезпечує стабільну насіннєву продуктивність [12, 14]. Поряд 3 цим, питання застосування добрив за багаторічного циклу вирощування рослин світчграсу розкрито не в повній мірі.

Упродовж періоду вегетації енергетичні культури виносять певну кількість основних елементів живлення: азоту, фосфору та калію, а також мікроелементи, у зв'язку з чим може відбуватись виснаження грунту. Тому виникає необхідність вивчення шляхів збереження та відновлення балансу гумусу та NPK у грунті за підживлення рослин в період вегетації, особливо під час вирощування енергетичних культур на збіднених на поживні речовини грунтах, еродованих та деградованих землях.

На даний час зареєстровано значну кількість добрив і препаратів для позакореневого підживлення рослин, вплив деяких із них на енергетичні культури вже вивчений, інших - недостатньо. Одними 3 таких є комплексні добрива 3 групи Кристалони (особливий, жовтий, коричневий), які мають хелатну природу, містять у своєму складі збалансоване співвідношення макро- та мікроелементів, застосовуються в інтенсивних технологіях вирощування зернових культур, та як доповнення до традиційної системи мінерального живлення рослин [7].

Мета досліджень полягала у встановленні впливу весняного підживлення на формування кількісних показників рослин та урожайності надземної вегетативної маси проса прутоподібного за багаторічного циклу вирощування.

Відповідно до поставленої мети досліджень передбачалось вирішення наступних завдань:

1. Визначити мінливість кількісних показників рослинного фітоценозу проса прутоподібного залежно від застосування підживлення.

2. Встановити вплив підживлення на урожайність проса прутоподібного за сухою вегетативною масою.

3. Провести кореляційно-регресійний аналіз кількісних показників рослин з урожайністю фітомаси проса прутоподібного.

Методика проведення досліджень. Експериментальна робота виконана на базі Полтавської державної аграрної академії згідно 3 міжнародною науковою тематикою «Pellets for Power» (2011-2013 рр.) та державної науково-дослідної теми «Агроекологічні засади вирощування енергетичних культур в умовах України» (20142017 рр.).

Дослід був закладений у центральній частині Лісостепу на деградованих грунтах, що мали наступні агрохімічні характеристики: вміст гумусу - 2,07 \%; азоту - 44,8; фосфору - 65,0 і калію 113,0 мг на 1 кг грунту.

Протягом 2011-2015 років вивчався сорт світчграсу Кейв-ін-рок на різних варіантах: варіант 1 - контроль (без підживлення рослин), варіант 2 одноразове позакореневе підживлення рослин «Кристалоном особливим» у період відновлення вегетації, варіант 3 - дворазове позакореневе підживлення рослин «Кристалоном особливим» у період відновлення вегетації і весняного кущіння.

Кристалон особливий - водорозчинне комплексне добриво норвезької компанії «Норск Гідро» зі збалансованим співвідношенням макро- та мікроелементів на хелатній основі. Норма внесення 4 кг/га, об'єм робочого розчину 230 л/га. Містить, \%: всього $\mathrm{N}-18,0\left(\mathrm{~N}_{-} \mathrm{NO}_{3}{ }^{-}-4,9 ; \mathrm{N}^{-} \mathrm{NH}_{4}{ }^{+}-3,3\right.$; $\left.\mathrm{N}-\mathrm{NH}_{2}-9,8\right) ; \mathrm{P}_{2} \mathrm{O}_{5}-18,0 ; \mathrm{K}_{2} \mathrm{O}-18,0 ; \mathrm{MgO}-3,0$; $\mathrm{S}-2,0 ; \mathrm{B}-0,025 ; \mathrm{Cu}-0,01 ; \mathrm{Mn}-0,04 ; \mathrm{Fe}-0,07$; Мо - 0,004; Zn - 0,025 [7, 11].

За проведення багаторічних досліджень застосовували як загальноприйняті методики [4], так і спеціальні - для закладки і проведення експерименту та обліку кількісних показників рослин $[9,13]$.

Урожайність фітомаси світчграсу визначали шляхом скошування снопових зразків, їхнього зважування, висушування відібраної проби та перерахунку на суху масу з урахуванням вологості сировини [15].

Отримані результати досліджень, що апробовані в досліді, обробляли за сучасними методами 


\section{СІЛЬСЬКЕ ГОСПОДАРСТВО. РОСЛИННИЦТВО}

статистики із застосуванням ліцензійних комп'ютерних програм Excel та Statistica 6.0.

Результати досліджень засвідчують про суттєвий вплив підживлення на кількісні показники рослин світчграсу сорту Кейв-ін-рок (табл. 1-2).

Кількість стебел у рослин світчграсу третього - п’ятого років вегетації мала тенденцію до збільшення, відповідно за роками - від 213,5 до 395,4 шт./м.П. (контрольні варіанти); на варіантах із підживленням «Кристалоном» - від 245,8 до 437,2 шт./м.п. У середньому, порівняно із контролем, застосування підживлення посівів проса прутоподібного збільшило даний показник на 66,5 шт./м.П.

Висота рослин, на варіантах без обробки посівів препаратом «Кристалон», варіювала у межах - від 141,5 до 192,4 см, а в разі застосування підживлення - від 167,9 до 213,5 см. При цьому, найбільші значення за даним показником було отримано на варіантах із дворазовим підживленням посівів. Порівняно із контролем, у середньому за роки дослідження, застосування підживлення збільшило висоту рослин на 34,1 см.

Кількісні показники рослин, особливо в разі застосування підживлення, мали певний вплив на динаміку урожайності сухої фітомаси світчграсу (див. рис.).

За роки дослідження урожайність сухої фітомаси світчграсу сорту Кейв-ін-рок змінювалася у межах від 2,9 до 11,5 т/га, у середньому за роки ста- новила 8,5 т/га (контроль); на варіантах із одноразовим підживленням - від 3,1 до 12,2 т/га, середнє - 9,0 т/га; за дворазового підживлення - від 3,2 до 13,1 т/га, у середньому - 9,6 т/га. Застосування позакореневого підживлення рослин світчграсу на перший - другий рік вегетації не має суттєвого ефекту на урожайність фітомаси, а розпочинаючи 3 третього року - даний захід збільшував цей показник та подовжував термін продуктивності посівів світчграсу.

За проведення кореляційно-регресійного аналізу було встановлено зв'язки між кількісними показниками рослин та урожайністю фітомаси світчграсу на фоні застосування весняного підживлення посівів (табл. 3).

Урожайність фітомаси проса прутоподібного iз вмістом сухої речовини та густотою стеблостою на третій рік вегетації культури має прямолінійний зв'язок середньої сили, що посилюється на четвертий - П'ятий рік вирощування на варіантах із підживленням рослин. Середню кореляцію висоти рослин і продуктивності фітоценозу світчграсу відмічено на четвертий рік вегетаціï, в інші роки - зв'язок не суттєвий. Це свідчить про те, що врожайність надземної вегетативної маси світчграсу в більшій мірі обумовлюється вмістом сухої речовини у фітомасі, кількістю стебел на одиницю площі, в меншій мірі висотою рослин за проведення весняного позакореневого підживлення.

\section{1. Вплив підживлення на кількісні показники (кількість стебел, шт./м.п.) світчграсу}

третього - п'ятого років вегетації, 2013-2015 pp.

\begin{tabular}{|c|c|c|c|c|}
\hline \multirow{2}{*}{ Варіанти (Фактор А) } & \multicolumn{3}{|c|}{ Рік (Фактор Б) } & \multirow{2}{*}{$\begin{array}{c}\text { Середнє за } \\
\text { роки }\end{array}$} \\
\hline & 2013 & 2014 & 2015 & \\
\hline Варіант 1 (контроль) & 213,5 & 316,7 & 395,4 & 308,5 \\
\hline Варіант 2 (одне підживлення) & 245,8 & 325,3 & 411,8 & 327,6 \\
\hline Варіант 3 (два підживлення) & 312,4 & 375,5 & 437,2 & 375,0 \\
\hline $\mathrm{HIP}_{05}$ (Фактор A) & 25,3 & 7,4 & 15,3 & - \\
\hline $\mathrm{HIP}_{05}$ (Фактор Б) & \multicolumn{4}{|c|}{9,8} \\
\hline
\end{tabular}

\section{2. Вплив підживлення на кількісні показники (висота рослин, см) світчграсу} третього - n'ятого років вететаціï, 2013-2015 pp.

\begin{tabular}{|c|c|c|c|c|}
\hline \multirow{2}{*}{ Варіанти (Фактор А) } & \multicolumn{3}{|c|}{ Рік (Фактор Б) } & \multirow{2}{*}{$\begin{array}{c}\text { Середнє за } \\
\text { роки }\end{array}$} \\
\hline & 2013 & 2014 & 2015 & \\
\hline Варіант 1 (контроль) & 141,5 & 155,8 & 192,4 & 163,2 \\
\hline Варіант 2 (одне підживлення) & 167,9 & 177,3 & 208,4 & 184,5 \\
\hline Варіант 3 (два підживлення) & 182,1 & 196,4 & 213,5 & 197,3 \\
\hline $\mathrm{HIP}_{05}$ (Фактор A) & 13,2 & 17,4 & 3,8 & - \\
\hline $\mathrm{HIP}_{05}$ (Фактор Б) & \multicolumn{4}{|c|}{8,7} \\
\hline
\end{tabular}




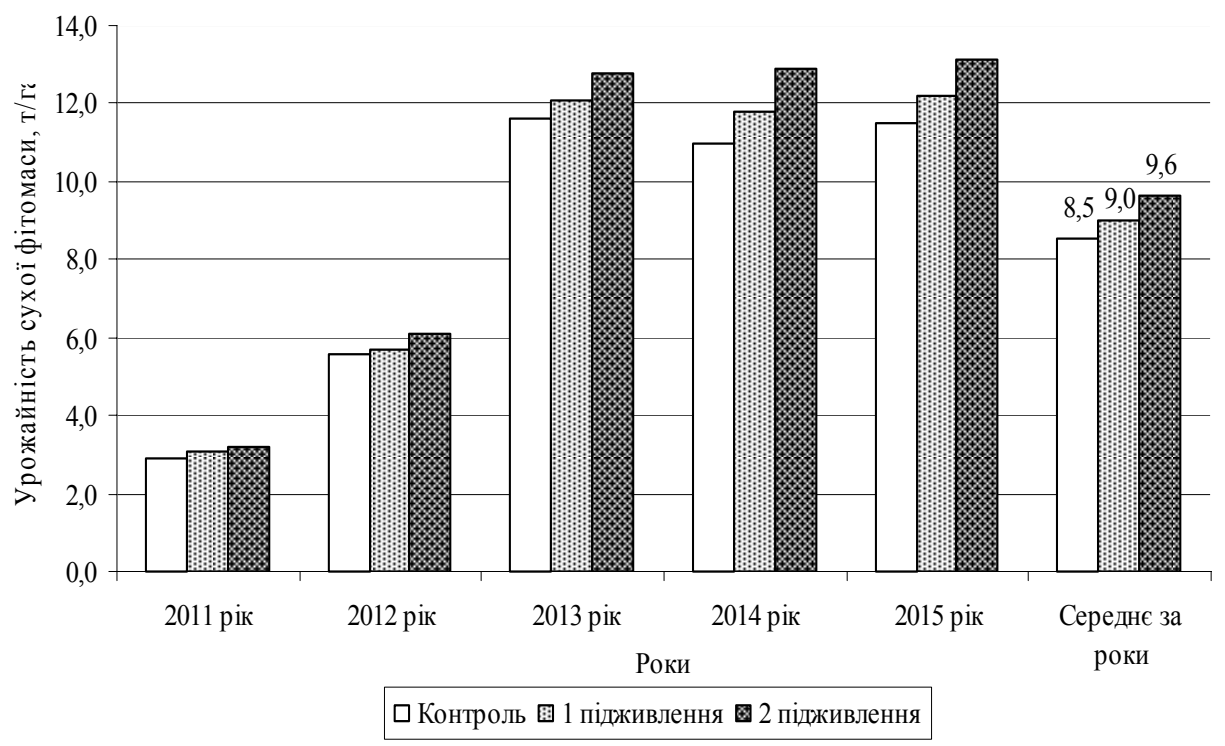

$\mathrm{HIP}_{05}$ (рік) - 1,3 т/га, $\mathrm{HIP}_{05}$ (підживлення) - 0,57 т/га.

Вилив підживлення на урожайність сухої рітомаси світчграсу сорту Кейв-ін-рок, 2011-2015 рр.

3. Кореляційні залежності міжн урожайністю фітомаси світчграсу сорту Кейв-ін-рок та кількісними показниками рослин третього-п'ятого року вететації, 2013-2015 pp.

\begin{tabular}{|l|c|c|c|}
\hline \multirow{2}{*}{\multicolumn{1}{|c|}{ Кількісні показники }} & \multicolumn{3}{|c|}{ Вегетаційний рік } \\
\cline { 2 - 4 } & третій & четвертий & п’ятий \\
\hline Висота рослин, см & 0,46 & $0,51^{*}$ & 0,52 \\
\hline Кількість рослин, шт./м.п. & $0,63^{*}$ & $0,68^{*}$ & $0,84^{*}$ \\
\hline Вміст сухої речовини у фітомасі, т/га & $0,65^{*}$ & $0,85^{*}$ & $0,82^{*}$ \\
\hline
\end{tabular}

Примітка: * - зв'язки суттєві на $5 \%$ рівні значущості.

\section{Висновки:}

1. Застосування весняного позакореневого підживлення фітоценозу проса прутоподібного сорту Кейв-ін-рок препаратом «Кристалон» суттєво збільшує вміст сухої речовини у фітомасі (у середньому на 23,7 \%) та кількість стебел (у середньому на 66,5 шт./м.п.) - елементів продуктивності, що $є$ визначальними у зростанні урожайності культури. Це підтверджується суттєвим кореляційним зв'язком між цими показни-

\section{БІБЛІОГРАФІЯ}

1. Бондаренко Г. В. Енергетична безпека як визначальна складова економічної незалежності України / Г. В. Бондаренко, В. О. Щерба // Актуальні проблеми економіки. - 2009. - №6. C. $55-58$.

2. Закон України «Про ратифікацію Рамкової конвенції ООН про зміну клімату» від 29.10.1996 № 435/96-ВР // Відомості Верховної Ради України. - 1996. - № 50. - 277 с.

3. Закон України «Про ратифікацію Кіотського протоколу до Рамкової конвенції ООН про ками та урожайністю фітомаси культури третього-п'ятого років вегетації.

2. Найбільша врожайність (більше 12,0 т/га) сухої надземної вегетативної маси проса прутоподібного сорту Кейв-ін-рок формується за проведення дворазового підживлення препаратом групи «Кристалонів» у періоди відновлення вегетації та весняного кущіння рослин на третійп'ятий рік вирощування культури.

зміну клімату» від 4.02.2004 №1430-IV. [Електронний ресурс]. - Режим доступу : http://zakon4.rada.gov.ua/laws/show/1430-15.

4. Доспехов Б. А. Методика полевого опыта / Борис Алексеевич Доспехов. - М. : Колос, 1985. $336 \mathrm{c}$.

5. Дубініна М. В. Інституційні особливості розвитку біоенергетики / М. В. Дубініна // Зб. наук. праць Вінницького НАУ. - Вінниця, 2012. Т. 1. - Вип. 2(64). - С. 31-36. 
6. Енергетичний та екологічний аналіз технологій виробництва електроенергії з твердої біомаси / Г. Г. Гелетуха, Т. А. Желєзна, А. І. Баштовий // Журнал «Промислова теплотехніка», 2017. Т. 39. - Вип. 1. - С. 58-64.

7. Карамазін I. Нетрадиційні добрива для традиційних культур / I. Карамазін, С. Адаменко // Пропозиція. - №4. - 2004. - С. 36-37.

8. Курило В. Л. Біоенергетика в Україні: стан та перспективи розвитку / В. Л. Курило, М. В. Роїк, О. М. Ганженко // Біоенергетика. 2013. - Вип. 1. - С. 5-10.

9. Методичні рекомендації з проведення основного та передпосівного обробітку грунту і сівби проса лозовидного / [Курило В. Л., Гументик М. Я., Гончарук Г. С. та ін.]. - К. : Інститут біоенергетичних культур і цукрових буряків НААН, 2012. $26 \mathrm{c}$.

10. Национальный кадастр антропогенных выбросов из источников и абсорбции поглотителями парниковых газов в Украине за 1990-2009 гг. [Електронний ресурс]. - Режим доступу : http://unfecc. int/national_reports/annex_i_ ghg inventories/national_inventories_submissions/items/ 5888. php.

11. Перелік пестицидів і агрохімікатів, дозволених до використання в Україні. - К. : Юнівест Медіа, 2012. -832 c.

12. Рахметов Д. Б. Panicum virgatum L. - перспективний інтродуцент у Національному ботанічному саду ім. М. М. Гришка НААН України / Д. Б. Рахметов, О. М. Вергун, С. О. Рахметова // Інтродукція рослин. - Вип. 3(63). - 2014. - С. 4-12.

13. Рӧ̈к М. В. Методика проведення експертизи сортів проса прутоподібного (Panicum virgatum L.) на відмінність, однорідність і стабільність : Код UPOV : PANIC_VIR / [M. В. Роїк, Д. Б. Рахметов, С. М. Гонтаренко та ін.]. - К. : УIECP, 2012. - $15 \mathrm{c}$.

14. Kulyk M. Impact of seeding terms and row spacing on yield of switchgrass phytomass, biofuel and energy output // Annals of Agrarian Science. Volume 14, Issue 4. - P. 331-334.

15. Kulyk M. Methods of calculation productivity phytomass for switchgrass in Ukraine / M. Kulyk, W. Elbersen. - Poltava, 2012. - 10 p. 